\title{
Ecological stoichiometry in detritus-based ecosystems with a special focus on forested headwater streams
}

\author{
Michael Danger
}

University of Lorraine, LIEC, Metz, France.

LTSER France, Zone Atelier du Bassin de la Moselle - 54506 Vandœuvre-lès-Nancy, France.

* Corresponding author: michael.danger@univ-lorraine.fr

Received: 01/02/19 Accepted: 23/07/19

\begin{abstract}
Ecological stoichiometry in detritus-based ecosystems with a special focus on forested headwater streams

Ecological stoichiometry has been defined as the study of the balance of chemical elements in ecological interactions. This approach was initially aimed at understanding the causes and consequences of elemental imbalances in nature, from molecular to ecosystem levels. Despite the theoretically wide applicability of this conceptual framework, most ecological stoichiometry studies have been restricted to the plant - herbivore interface and these studies have only rarely explored consequences of elemental imbalances at the community and ecosystem scales.

Detritus-based ecosystems can be defined as ecosystems receiving most of their energy inputs under the form of detritus, i.e. dead organic matter. These detritus are generally dominated by dead plant material, which most often correspond to strongly nutrient-depleted organic matter. Stoichiometric imbalances are thus expected to be particularly exacerbated in this kind of ecosystems. Mainly fueled by allochthonous detritus (e.g. dead wood, leaf litter), forested headwater streams represent typical detritus-based ecosystems, but also well-suited ecosystem models for understanding the consequences of elemental imbalances in nature.

In this paper, after summarizing the main concepts of ecological stoichiometry and the stoichiometric peculiarities of detritus-based ecosystems, I will present, based on a selection of literature examples, a list of stoichiometric questions that have been investigated in forested headwater stream ecosystems in the past few years. I will finally present a non-exhaustive list of research perspectives that should deserve, in my opinion, particular attention for improving our understanding of the consequences of elemental imbalances in detritus-based ecosystems.
\end{abstract}

Key words: stoichiometry, detritus-based ecosystems, forested headwater streams, streams

\section{RESUMEN}

\section{Ecología estequiométrica en ecosistemas detrito-dependientes con especial énfasis en arroyos de cabecera}

La estequiometria ecológica ha sido definida como el estudio del balance de los elementos químicos en interacciones ecológicas. Este enfoque se dirigió inicialmente a entender las causas y consecuencias de los desequilibrios en la composición elemental en la naturaleza, desde el nivel molecular al nivel ecosistémico.

Los ecosistemas detrito-dependientes se pueden definir como ecosistemas que reciben la mayor parte de su energía en forma de detritos (materia orgánica muerta). Estos detritos están generalmente dominados por restos de plantas muertas, que por lo general presentan una concentración de nutrientes muy baja. Por ello, se espera que los desequilibrios estequiométricos sean particularmente importantes en este tipo de ecosistemas. Los arroyos de cabecera, principalmente alimentados por detritos de origen alóctono (madera muerta, hojas en descomposición), representan los típicos ecosistemas detrito-dependientes y sirven como modelo para entender mejor los desequilibrios elementales en la naturaleza.

En este manuscrito, después de resumir los conceptos básicos de la ecología estequiométrica y las peculiaridades de la estequiometría de los ecosistemas detrito-dependientes, presentaré, a partir de una serie de ejemplos de la literatura, una lista de cuestiones sobre estequiometria que se han investigado en los arroyos de cabecera en los últimos años. Finalmente presentaré, una lista no muy exhaustiva, de perspectivas de investigación que merecen, en mi opinión, atención particular para 
entender mejor las consecuencias de los cambios en los balances elementales en los ecosistemas detrito-dependientes.

Palabras clave: estequiometria, ecosistemas detrito-dependientes, arroyos de cabecera

\section{INTRODUCTION}

Ecological Stoichiometry (ES) corresponds to an approach of ecology taking into account the balance between several chemical elements during organisms' interactions and ecological processes (Elser et al., 1996; Sterner \& Elser, 2002). All living organisms are composed of several chemical elements associated into organic matter in more or less variable amounts, for example nitrogen $(\mathrm{N})$, phosphorus $(\mathrm{P})$, carbon (C), iron (Fe), silica $(\mathrm{Si})$, potassium $(\mathrm{K})$, etc. The main interest of this approach relies on the fact that it takes into account the elemental composition (often expressed as ratios, for example $\mathrm{C}: \mathrm{N}$ or $\mathrm{N}: \mathrm{P}$ ratios) of living organisms involved in ecological interactions, thus making it possible to explicitly consider the couplings between biogeochemical cycles and organisms via chemical elements. The ecological stoichiometry conceptual framework is mainly based on the differences in chemical composition between interacting organisms, which can both influence the efficiency and ecosystem consequences of their trophic relationships, but also play a role in the outcome of non-predatory interactions (e.g. competition vs. mutualism). Ecological stoichiometry, although formalized quite recently (Sterner \& Elser, 2002), finds its origin in much older approaches. Lotka (1925), in his book entitled Elements of Physical Biology, was certainly the first to evoke the importance of considering the composition of living organisms in the study of their interactions and their impacts on their environment. The rest of the framework development will be made by Reiners, in 1986, who proposed a mechanistic view of the connections between the basic composition of organisms, environmental constraints, and ecosystem consequences.

Ecological stoichiometry has been initially developed by limnologists, and this approach has now been successfully transferred to diverse ecosystem types, including terrestrial and marine ecosystems. Yet, more than 15 years after the publication of the ecological stoichiometry book (Sterner \& Elser, 2002), it is still noticeable that a large majority of these studies have been restricted to the investigation of plant-herbivore interactions. The stoichiometric aspects of detritus-decomposers interactions have, in comparison, received far less attention (see Evans-White \& Halvorson, 2017). The aim of this paper is not to propose a thorough review of all the studies dealing with ecological stoichiometry in detritus-based ecosystems, but to present how taking into account elemental imbalances already has changed or might change our view of the functioning of ecosystems, more specifically focusing on forested headwater streams. After a short reminder of the main principles of ecological stoichiometry and of the main features of detritus-based headwater streams, I will present some selected scientific questions concerning detritus-based ecosystems functioning that have been tackled in the past 15 years and that benefited from the Ecological Stoichiometry framework. I will finally conclude by proposing a list of perspectives that I would find interesting to deal with in the future in order to increase our understanding of detritus-based ecosystems functioning, but also our general knowledge on the consequences of elemental imbalances in ecosystems.

\section{Basic principles of Ecological Stoichiometry}

Ecological stoichiometry is based on three basic principles. First of all, living organisms are all built of the same main chemical elements, but each species has specific requirements in these chemical elements that will differ from those of other species. These requirements seem to be globally well related to phylogeny. For example, the differences in elemental composition of animals within a family of organisms is generally much smaller than the differences between this family and other families of living organisms 
(e.g. Woods et al., 2004; Hendrixson et al., 2007). Elemental composition of organisms is generally used as a proxy of organisms' elemental requirements, and the difference between resources and consumers' elemental composition is commonly supposed to indicate the degree of elemental imbalance during trophic interactions. Yet, a proper evaluation of elemental requirements of an organism should also include the metabolic costs of using a particular resource (see Question 3, below). Sterner \& Hessen (1994), followed by Frost et al. (2006), proposed to calculate organisms Threshold Elemental Ratios (TER), i.e. the elemental ratios in resources where growth limitation switches from one element to another. This TER explicitly takes into account the assimilation efficiencies, the ingestion rates, and the respiration rates of consumers, in addition to the internal elemental composition of the consumer (Frost et al., 2006).

The second basic principle of ecological stoichiometry corresponds to elemental homeostasis. In the context of ecological stoichiometry, homeostasis is the ability of living organisms to control their internal elemental composition, so that the latter is less variable than the resources they consume (Kooijman, 2000; Sterner \& Elser, 2002). Although strict elemental homeostasis has been discussed or refuted for several taxa (Cross et al., 2003; Small \& Pringle, 2010; Halvorson et al., 2015), it can be closely approximated for numerous metazoans (Persson et al., 2010, but see Question 4, below). In contrast with metazoans, primary producers are generally considered as non-homeostatic, i.e. their elemental composition will vary greatly depending on the availability of resources in the environment, these organisms being able to store nutrient in excess (a process commonly called luxury consumption; Chapin, 1980).

Finally, the third basic principle corresponds to the law of conservation of mass. In other words, the elements available at the beginning of the ecological interaction are necessarily found after this interaction, but in different forms or compartments. The gap between consumer requirements and the availability of nutrients in resources will be considered as a stoichiometric constraint. The latter, for example, may affect the growth rate of the organism, but also the quantity and ratios of the excreted elements (e.g. Elser \& Urabe, 1999). In this way, it is also possible to extrapolate the consequences of these stoichiometric constraints to larger scales, for example to population dynamics (Moe et al., 2005), to community structures (e.g. Elser et al., 1998), or to matter and energy fluxes within ecosystems (e.g. Cebrian et al., 2009).

\section{Detritus-based ecosystems with a special focus on forested headwater streams}

\section{What are detritus?}

Based on the pioneer work of Swift et al. (1979), Moore et al. (2004) defined detritus as "all forms of dead organic matter". In their synthesis, these authors noted that in ecology, although detritus has long been included in discussions, and that much is known about the origin and decomposition of detritus, their integration into the study and understanding of food webs is generally lacking.

In ecosystems, detritus can have very different origins and forms, including all types of dead plant tissues (e.g. dead leaves, dead wood, macrophytes, and dead algae), dead animals, dead microorganisms, faeces, as well as dissolved organic matter excreted or exuded (e.g. exopolysaccharides, dissolved organic matter, root or leaf exudates). Nevertheless, if one refers to the fact that most of the energy present in organic matter comes from primary producers, and that about 90 $\%$ of this primary production is never consumed by herbivores and ultimately ends in the detritus stock (Cyr \& Pace, 1993; Hairston \& Hairston, 1993; Polis \& Strong, 1996), we can deduce that the vast majority of detritus is of plant origin. This last observation does not necessarily mean that the detritus originating from heterotrophic consumers is negligible, because many parameters could affect the role of detritus in ecosystems. Among these parameters, the quality and decomposability of detritus might play a fundamental role. In ecosystems, especially in ecosystems that are subject to nutrient limitations, most organisms have been selected for reabsorbing and retaining limiting nutrients before senescence (plants; Killingbeck, 1996; Nooden et al., 1997) 
or excretion of wastes (animals; Anderson et al., 2004). Thus, detritus are most often extremely nutrient depleted, containing generally very low $\mathrm{N}$ and $\mathrm{P}$ contents (Martinson et al., 2008).

\section{Towards the recognition of "green" and "brown" food webs}

Detritus has long been acknowledged as an important or even preponderant component of ecosystems. In particular, Lindeman (1942) positioned the detritus (called "ooze") at the heart of his vision of lacustrine food webs. Later, Odum (1969) will also point out that detritus supports a large part of ecosystem functioning, distinguishing between compartments of herbivore-based food webs, in which energy comes initially from living primary producers, and compartments based on decomposers, in which energy comes from dead organic matter. These food webs will then be commonly referred to as "green" and "brown" food webs, respectively. While most ecosystems are fueled concomitantly by the two types of energy, transfer pathways of organic matter from green and brown origins are still too often studied independently, and taking into account the interactions between both parts of food webs might be of great importance for understanding ecosystem functioning (Zou et al., 2016; Quévreux et al., 2018).

\section{Forested headwater streams as an example of "detritus-based ecosystem"}

As discussed above, many authors have distinguished "brown food webs" from "green food webs" based on the energy source at the base of the food web. Similarly, it is common to hear of "detritus-based ecosystems" as opposed to "ecosystems based on living primary producers". This

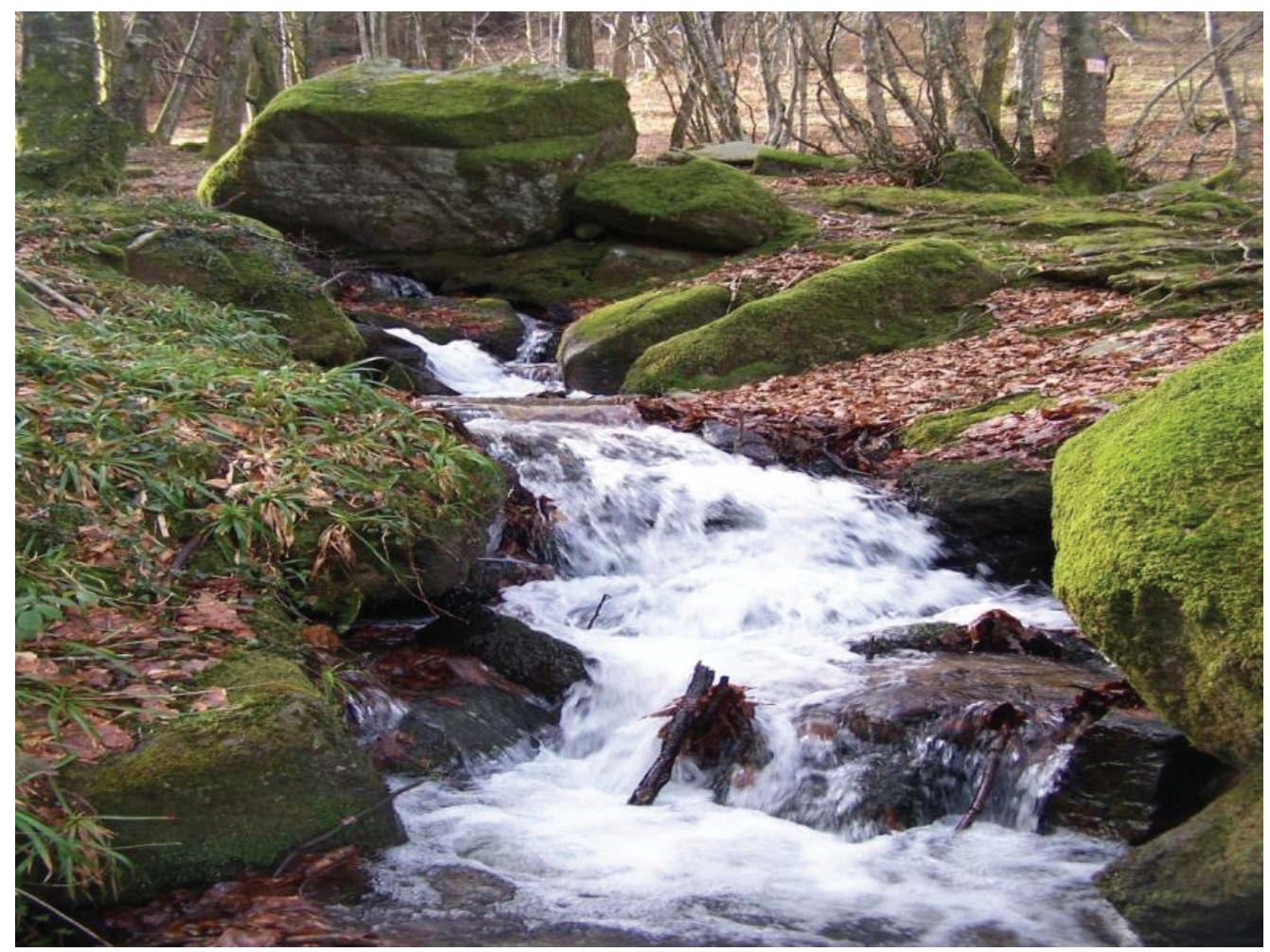

Figure 1. Example of a typical forested headwater stream in the Montagne Noire, France. In autumn, leaf litter represents the main input of organic matter, accumulating in the stream. Ejemplo de un arroyo de cabecera típico en Montangne Noire, Francia. En otoño, la hojarasca que se acumula en el arroyo representa el mayor aporte de materia orgánica. 
concept is used in both freshwater, marine, and terrestrial environments, and distinguishes between ecosystems whose main source of energy consists of detrital matter or living plant organic matter. Forested headwater streams are typically known as receiving most of their energy under the form of allochthonous detrital organic matter, especially as dead wood and leaf litter (Fisher \& Likens, 1973, Fig. 1). Nevertheless, inputs of living organic matter are not excluded, especially at some periods of the year (e.g. insects, annelids, molluscs, pollen). Although greatly reduced in these ecosystems, autochthonous primary production is generally not null. Despite its reduced contribution to the stream C budget, this primary production might be more functionally important than initially expected (Danger et al., 2013a; Crenier et al., 2017).

Organisms involved in the functioning of these detritus-based streams are mainly represented by microbial decomposers, rare primary producers, invertebrates and some vertebrate species. Microbial decomposers are mainly represented by aquatic fungi - in particular aquatic hyphomycetes - and bacteria (Gessner et al., 1999), and play an essential role in the conditioning of detritus before these detritus are taken up by detritivores (Gessner et al., 1994). Other microbial actors, such as protozoa, are well present in these ecosystems but have been the subject of only a very small number of studies (Ribblett et al., 2005). Primary production is mainly ensured by benthic algae present within phototrophic biofilms, but can also be ensured by higher aquatic plants and/or bryophytes. Invertebrate and vertebrate organisms have, for their part, often been categorized in relation to their diets as detritivores, herbivores, carnivores. The functioning of forested headwater streams is therefore mainly based on brown food webs with a small green sub-compartment based on autotrophic primary production.

\section{Questioning ES in detritus-based, forested headwater streams}

The stoichiometric approaches, developed in the early 90's in lacustrine environments, were first restricted to the study of plant - herbivore interac- tions (see Sterner \& Elser, 2002). The first concrete applications of these approaches in the benthic systems have also been directed towards these same trophic groups (e.g. Frost \& Elser, 2002; Stelzer \& Lamberti, 2002). The transfer of stoichiometric concepts to detrital systems has been more recent. As noted by Martinson et al. (2008) followed by Evans-White \& Halvorson (2017), in spite of some pioneer work (e.g. Cross et al., 2003), stoichiometric approaches have long neglected detrital ecosystems and detritivores in particular. However, these ecosystems are mainly based on detritus that are most often characterized by very poor elemental quality, with extremely low nutrient contents. Moreover, specifically in the case of unpolluted headwater streams, the availability of nutrients (e.g. nitrogen and phosphorus) in the water column can be greatly reduced. These ecosystems are indeed known to respond strongly to nutrient inputs, highlighting the potential importance of nutrient limitations in these ecosystems (see review by Ferreira et al., 2015). As a consequence of these peculiarities, stoichiometric constraints in detritus-based ecosystems are expected to be among the highest that can be found on Earth (Cross et al., 2005; Martinson et al., 2008).

The following part of this manuscript will be dedicated to the discussion of some important scientific questions arising when considering the stoichiometry of forested headwater stream, and more generally, those of detritus-based ecosystems. All these questions and the scientific challenges that need to be overcome are summarized in Table 1.

\section{Question 1: What can explain variations in detri-} tus elemental content?

When considering forested headwater streams, leaf litter certainly represents one of the main energy and nutrient source for food webs (Fisher \& Likens, 1973; Wallace et al., 1999). The elemental composition (e.g. in terms of C:N and $\mathrm{C}: \mathrm{P}$ ratios) of these leaf litters are known to vary widely. The first and most well-known source of variation certainly concerns the large interspecific differences that can be found between leaf litter types (e.g. Ostrofsky, 1997; Hladyz et al., 2009). 
Table 1. Non-exhaustive list of research questions and the main scientific challenges arising when questioning ecological stoichiometry in detritus-based ecosystems. Lista, no exhaustiva, de preguntas y de los principales retos cientificos que aparecen cuando se cuestiona la ecología estequiométrica en los ecosistemas detrito-dependientes.

Question 1: What can explain variations in detritus elemental content?

Challenge 1: Understanding and predicting initial differences in detritus quality

Challenge 2: Understanding microbial decomposers stoichiometry (including fungi and bacteria)

Question 2: How can we measure the impact of detritus elemental content on detritivores life history traits?

Challenge 3: Disentangle detritus stoichiometry effects from those of other resources quality parameters

Challenge 4: Quantify the relative importance of stoichiometry and other bottom up limitations

Question 3: How can we quantify stoichiometric imbalances for detritivores?

Challenge 5: Taking into account detritus stoichiometric heterogenity

Challenge 6: Understanding what detritivores really feed on (species selectivity)

Challenge 7: Precisely quantifying consumers elemental requirements (consumers' TERs)

Question 4: Are all detritivores really homeostatic?

Challenge 8: What is the part of plasticity due to detritivores ontogeny and true non homeostasis

Challenge 9: Incorporate consumers elemental plasticity in stoichiometric models

Question 5: How can we predict detritivores community structures using ecological stoichiometry?

Challenge 10: Predict how stoichiometry explains competitive exclusion between species

Challenge 11: Develop a stoichiometric trait-based approach of community ecology

Challenge 12: Scale-up stoichiometric control of communities to impacts on ecosystem functioning

As an example, litters from $\mathrm{N}$-fixing species are known to present, on average, higher N-levels than litters coming from non-fixing ones (Hladyz et al., 2009). In addition to these interspecific variations, several studies reported large intraspecific differences, depending either on the latitude leaf litters were collected (Lecerf \& Chauvet, 2008) or on the nutrient availability in soils where the litter producing plants were grown (Graça \& Poquet, 2014; Biasi et al., 2017).

Then, when entering the aquatic ecosystem, detritus elemental quality for detritivores not only depends on the leaching of nutrient rich soluble compounds from leaf litter (occurring after the first hours-days of detritus immersion; Graça et al., 2005) but also on detritus microbial colonization and activity (Danger et al., 2016). The colonization of detritus by microorganisms will first depend on detritus traits, including the detritus elemental composition (Hladyz et al.,
2009). Then, the elemental composition of the detritus colonized by microorganisms will ultimately depend on the ability of microorganisms to acquire nutrients from the water column (Danger \& Chauvet, 2013; Manning et al., 2015; Danger et al., 2016). As all living organisms, microorganisms must acquire nutrients from their environment to fulfill their requirements, and elements in excess can be stored in microorganisms, at least in a certain extent. Both fungi and bacteria will be able to acquire nutrients from the detritus, and the maintenance of their stoichiometric balance will be ensured by the immobilization of nutrients from the water column (e.g. Cheever et al., 2012). Only a few studies investigated the elemental plasticity of microbial decomposers (see Danger et al., 2016 for a review). While some taxa seem to be relatively homeostatic, at least for some bacterial strains (Danger et al., 2008), most studies seem 
to indicate a large elemental plasticity of these decomposers, especially for phosphorus (Chrzanowski \& Kyle, 1996; Godwin \& Cotner, 2014; Manning et al., 2015; Gulis et al., 2017). This elemental plasticity seems to be the rule at the community level (Danger et al., 2008; Godwin \& Cotner, 2014). The putative stoichiometric controls of microbial community structures occurring in detritus, in particular the respective roles of nutrients originating from the detritus and from the water column remain to be tested experimentally. In addition, the observation that mean $\mathrm{C}: \mathrm{N}$ and $\mathrm{C}: \mathrm{P}$ values of fungal biomass are much higher than those of bacteria (Danger et al., 2016) question the stoichiometric control of fungi over bacteria on the low nutrient detrital resources. Finally, from a more operational point of view, it can be noted that the plasticity of detritus elemental composition has recently been proposed for predicting nutrient limitation in aquatic ecosystems, with detritus $\mathrm{C}: \mathrm{N}: \mathrm{P}$ ratios giving an indication of the relative availability of different nutrients in ecosystems (Farell et al., 2018).

Question 2: How can we measure the impact of detritus elemental content on detritivores life history traits?

Using laboratory feeding trials (González et al., 2014; Fuller et al., 2015) or field experiments (e.g. Friberg \& Jacobsen, 1999; Cross et al., 2007; Danger et al., 2012; Demi et al., 2018), several studies investigated the relationship between detritus $\mathrm{N}$ and/or P content and detritivores growth. While most studies showed significant correlations between litter $\mathrm{N}$ and/or $\mathrm{P}$ content and consumers growth, one cannot exclude that detritus stoichiometry co-varies with other important factors. As discussed earlier, changes in detritus elemental composition occur concomitantly with microbial colonization and mycelium development. Thus, higher detritus elemental content might also come with more palatable and more digestible detritus for detritivores, but also with drastic changes in the biochemistry of detritus material (changes in leaf litter lipids, soluble sugars and polyphenols, as well as lignin contents; Suberkropp et al.,
1976). Limiting these confounding factors requires an experimental control of detritus elemental content. In lakes, elemental quality of phytoplankton resources has generally been manipulated by applying short-term $(\leq 6 \mathrm{~h})$ nutrient pulses, leading to fast and large increases in phytoplankton elemental content with reduced changes in primary producers' biomass or other resource quality parameters (e.g. essential fatty acid profiles; Elser et al., 2001). Taking advantage of the largely non-homeostatic elemental composition of both fungi and bacteria (Danger et al., 2016), a protocol has been developed to manipulate detritus elemental content, letting first aquatic fungi or natural microbial consortia colonize detritus in nutrient-poor conditions before exposing detritus to short nutrient pulses in the laboratory (Danger $e t$ al., 2013b). Microbial immobilization was shown to lead to large changes in leaf litter elemental content over a 2 to 3 days period, without changing microbial biomass. Using this procedure, low leaf litter $\mathrm{C}: \mathrm{P}$ ratios were shown to increase the growth and the survival of a detritivore crustacean species, Gammarus fossarum Koch (Danger et al., 2013b). Using the same detritivore species and a similar protocol, Arce-Funck et al. (2016) showed that feeding on low C:P resources was directly related to higher energy storage as well as higher locomotor activity, while Rollin et al. (2018) showed that feeding on higher quality resources led to reduced intermolt phase length, fastening the reproduction. Using such a nutrient enrichment procedure, the impact of detritus stoichiometry on detritivores life history traits could now be generalized to other taxa, and could also permit to test in more details the different physiological and ecological impacts of nutrient imbalances in detritus-based ecosystems.

Question 3: How can we quantify stoichiometric imbalances for detritivores?

In numerous stoichiometric studies, elemental imbalance has simply been defined as the difference between the elemental composition of the consumer and that of the resource (e.g. Cross et al., 2005). Yet, using these bulk elemental compo- 
sitions might sometimes lead to large inaccuracies in the evaluation of stoichiometric imbalances, and future research might require more attention both at the resource and at the consumer levels.

First of all, detritus generally represent highly heterogeneous resources. For example, when considering leaf litter, main veins generally exhibit large differences in their physical (thicker and tougher material) and chemical (higher lignin and fiber contents; Graça et al., 2005) characteristics with the rest of these detritus. In addition, the microscopic chemical composition of a single leaf litter can also vary much, depending for example on initial heterogeneity in leaf litter quality and subsequently on differences in the intensity of microbial colonization (Grimmett et al., 2009). Second, detritivores are far much more selective than what was originally thought. These invertebrates have long been considered as foraging only on detritus, but several studies found a non-negligible amount of algae, bryophytes, or animals in detritivores guts (e.g. in gammarids: Felten et al., 2008; Crenier et al., 2017). In addition, Lauridsen et al. (2014), measuring the elemental composition of invertebrate gut contents in comparison with the C:N:P ratios of the consumers, showed that the elemental imbalances were still present but far less pronounced when considering ingested vs. bulk detritus material. Invertebrates were able to select for the highest quality patches on the leaf litter.

The last important question when measuring elemental imbalances for a consumer deals with how we can really apprehend consumer stoichiometric requirements. For simplicity purposes, most studies directly consider elemental composition of organisms as a good proxy of their elemental requirements. Yet, such simplifications totally omit the metabolic and biochemical costs necessary for processing and assimilating the diet. Evaluating the Threshold Elemental Ratio (TER; Frost et al., 2006), i.e. the ratio at which the nutrient limitation of consumers growth switches from one element to another, permits to estimate the real elemental requirements of an organism. Consumers TERs can either be estimated mathematically, based upon the knowledge of consumers ingestion, assimilation, and respiration rates (Frost et al., 2006), or measured experimentally (e.g. Boersma \& Elser, 2006; Halvorson et al., 2015; Khattak et al., 2018). On the one hand, the theoretical approach has the advantage to be generalizable to a large number of taxa. However, this approach requires a number of strong assumptions, and some parameters might be more variable than what is commonly thought. For example, ingestion and assimilation rates may vary considerably from one resource to another (Urabe et al., 2018), and metabolic rates of consumers are highly sensitive to resources stoichiometry (Ruiz et al., 2018). On the other hand, experimentally measuring consumers TERs requires to strictly control resources elemental quality (see Question 2, above) in order to quantify consumers growth along a gradient of resources stoichiometry. Such measurements have, to my knowledge, only been carried out on a very restricted number of species (e.g. Boersma \& Elser, 2006; Benstead et al., 2014; Khattak et al., 2018), and even more rarely on detritivores (Halvorson et al., 2015). Finally, it must be noted that while consumers' TERs have long been considered as invariable, recent studies showed that this parameter might be largely influenced by temperature in ectotherms, temperature affecting differentially both consumers' growth and metabolic rate (Ruiz et al., 2019).

\section{Question 4: Are all detritivores really homeostatic?}

One of the central tenets of ecological stoichiometry framework relies on the fact that secondary consumers exhibit higher elemental homeostasis than their resources, allowing predictions on consumer responses to elemental imbalances (Sterner \& Elser, 2002). In the past 15 years, several studies questioned this principle in streams, either in natural conditions (comparison of taxa from streams naturally more or less rich in P: Small \& Pringle, 2010) or in experimental contexts (streams supplemented with nutrients; Cross et al., 2003; laboratory study: Halvorson et al., 2015). While some taxa seem to be able to store, to some extent, $\mathrm{C}$ and/or nutrients, Halvorson \& Small (2016) stressed the difficulty to use field data for evaluating organisms' homeostasis. For example, elemental composition of consumers is known to vary with organisms' size 
and/or ontogeny. Young and/or fast growing life stages of aquatic invertebrates are generally richer in nutrients, i.e. with lower C:nutrient ratios, than older and/or slow growing ones (e.g. in Daphnia; De Mott et al., 1998; in stream macroinvertebrates: Back \& King, 2013). The best way to evaluate organisms' abilities to maintain their homeostasis is to do it experimentally, controlling the elemental composition of the resources. Using such controlled experiments, Halvorson et al. (2015) were able to show that the trichoptera Pycnopsyche lepida Hagen deviates from strict homeostasis, while Danger et al. (2013) found that the crustacean G. fossarum was able to maintain constant $\mathrm{C}: \mathrm{N}: \mathrm{P}$ ratios when grown for 5 weeks along a gradient of $\mathrm{P}$ availability in leaf litter.

Some authors also recently criticized the way elemental homeostasis is measured (Meunier et al. 2014). Elemental homeostasis has long been evaluated through the measurement of the slope of the relationship between the log-transformed elemental composition of consumers and those of the resources (either 1/slope: Sterner \& Elser, 2002 or directly the slope: Persson et al., 2010). However, using such log-transformed data impede any fine characterization of consumers plasticity. Meunier et al. (2014) suggested to avoid using these transformations and analyze data on large gradients of resources quality. Using resource quality gradients would permit to separate species between two large categories: conformers (formerly called the non-homeostatic organisms), that are able to store all nutrients they receive between definite boundaries but who lose these capabilities when elemental imbalances exceed some threshold values, and regulators (formerly called the homeostatic organisms), that maintain their elemental composition quite constant, except when exposed to extreme elemental imbalances in their resources (Meunier et al., 2014). Using this approach, that again requires to use resource elemental quality gradients, would permit to understand in more depth the real capabilities of species to maintain their elemental homeostasis and to precisely quantify the thresholds above and below which the organisms are no more able to control these capabilities. Such data could then be used for predicting, in addition to species TERs, the outcome of species interactions when exposed to different resources constraints.

Question 5: How can we predict detritivores community structures using ecological stoichiometry?

Ecological stoichiometry framework has been initially thought to understand the causes and effects of elemental imbalances at all biological levels, from molecules to community and ecosystems. Yet, to date, most studies dealing with ecological stoichiometry have been carried out at the individual or population level (Cherif et al., 2017). For plant communities, resource ratio theory (Tilman, 1980, 1982, based upon MacArthur, 1972) mainly investigates species coexistence or exclusion as a function of the ratio of resources available in the environment. These predictions rely on the a priori knowledge of plants minimal requirements for the different nutrients. Quite similarly, applying ecological stoichiometry for consumers at the community level would, at least partly, consists in evaluating the intensity of the stoichiometric imbalance between resources elemental content and the elemental requirements of each consumer species. Species exhibiting the smallest elemental imbalances with the available resources should ultimately dominate the community. Despite its potential importance for community ecology, only a few datasets testing this hypothesis are currently available. Among these, Evans-White et al. (2009) and Dang et al. (2009), working on stream macroinvertebrates, showed a significant negative relationship between total phosphorus in the stream water and the mean C:P content of consumers. Similarly, Cross et al. (2006, 2007) showed that nutrient enrichment of a small headwater stream strongly reduced elemental imbalances, leading to large increases in secondary production. More recently, Demi et al. (2019), using an in situ experimental manipulation of available N:P ratios in natural streams, showed that the $C: P$ ratio of detritus was a strong driver of the whole macroinvertebrate community composition, even if in this study, detritivore $\mathrm{C}: \mathrm{P}$ ratio was not a good predictor of community structure changes. Understanding the relative importance of 
stoichiometric constraints when compared to other potential drivers of detritivore community structure would undoubtedly benefit from other dataset, obtained in more diverse conditions.

\section{Some perspectives for stoichiometric approach- es in detritus-based ecosystems}

From individuals to communities and ecosystems: Develop stoichiometric trait approaches

The notion of "stoichiometric traits" in aquatic invertebrates is still in its infancy. To date, this type of trait has been mainly applied to plants (e.g. Arrigo, 2005; Litchman \& Klausmeier, 2008), but begins to be considered in animal organisms (e.g. Litchman et al., 2013; Yamamichi et al., 2015). Arrigo (2005) formalized the relationships between elemental ratios, growth and reproduction strategies in marine microorganisms, proposing that organisms with high $\mathrm{N}: \mathrm{P}$ ratios were close to $\mathrm{K}$-strategists, with moderate growth but with strong capacities of resources acquisition (high investment in N-rich enzymes; Elser et al., 1996). In contrast, r-strategists would have low N:P ratios, investing a large part of their energy for growth and/or reproduction (processes requiring high amounts of $\mathrm{P}$; Elser et al., 1996) but with reduced nutrient acquisition capabilities. Similar predictions could be made for animal communities, fast growing organisms being expected to have lower $\mathrm{N}: \mathrm{P}$ requirements than slow growing ones. In a recent opinion paper, Meunier et al. (2017) synthesized the different biological traits of species that can be related to elemental stoichiometry, and discussed the potential trade-offs potentially occurring between these traits. Developing stoichiometric trait-based approaches, and integrating these traits into the list of more commonly investigated traits could represent a very promising research avenue, permitting to relate the elemental composition of resources to community structure and nutrient biogeochemical cycles.

\section{Advocate for using more gradient approaches}

In the early stages of ecological stoichiometry development, most studies were investigating the effects of nutrient deficiencies in resources without considering that excessive amounts of nutrients could also be deleterious for organisms (e.g. Elser et al., 2001; Frost \& Elser, 2002). Yet, coping with nutrients in excess might also be energy consuming and directly impact consumers life history traits (Boersma \& Elser, 2006). Some species can adopt particular pre-digestive behaviors, modulating ingestion rates of resources or selecting resources, in order to minimize stoichiometric imbalances (e.g. Lauridsen et al., 2014). When ingested, species might then greatly differ in their abilities to assimilate, store, or eliminate elements in excess. For example, some species might increase their respiration, excretion or metabolic rate when $\mathrm{C}$ is in excess in resources (Darchambeau et al., 2003; Anderson et al., 2004; Ruiz et al., 2018), others might have some storage capacities (Cross et al., 2003; Halvorson et al., 2015). When $\mathrm{N}$ and $\mathrm{P}$ are in excess in resources, species may also increase their release of $\mathrm{N}$ and $\mathrm{P}$ through excretion, this release being also largely dependent on species metabolism (Allen \& Gillooly, 2015; Vanni \& McIntyre, 2016). Understanding such species-specific differences might be of major importance to scale up results obtained in stoichiometric studies to larger scales, namely communities and ecosystems. I suggest here that for measuring consumers TERs, evaluate the degree of organisms' homeostasis, and understand how each species cope with imbalanced resources, the use of controlled gradients of resources stoichiometry might represent an essential experimental step. Finally, investigating how these specific parameters are impacted by environmental stressors (e.g. temperature increase, pollutants) might also represent an important research avenue that would certainly add to the current knowledge on the response of consumers and consumers communities to current global changes (Frost \& Tuchman, 2005; Ferreira et al., 2010; Kendrick \& Benstead, 2013; Mas-Marti et al., 2015).

Taking into account the heterogeneity of resources in detritus-based ecosystems

For a long time, the elemental quality of resources has been studied in a very global way, working on 
coarse samples filtered (seston) or crushed (i.e. "bulk"). Nevertheless, many studies have shown that organisms are much more selective than they appeared at first, and the actual stoichiometric constraints that organisms face are certainly less pronounced than originally imagined. Filter-feeding organisms, such as daphnids, have already been shown as being able to select "patches" of algae more or less rich in nutrients (Schatz \& McCauley, 2007). As discussed previously, detritivores can select for the highest stoichiometric quality parts of the detritus (Lauridsen et al., 2014). Similarly, microbial decomposers do not use indistinctly all the detritus parts. For example, Fanin et al. (2013) showed that the elemental composition of microbial decomposers was more related to the composition of leachates than to that of decomposing litter, suggesting that these microorganisms do not directly use bulk leaf litter (at least in the short term) but preferentially use a part of this resource (e.g. soluble, more labile substances). All these results demonstrate the need to better understand the diet of organisms inhabiting detritus-based ecosystems and to evaluate what is actually ingested compared to what is available. The use of labelled specific compounds (Bec et al., 2011) might represent an interesting perspective for understanding the physiological mechanisms involved in decomposers and detritivores nutrition.

Investigating other potential limiting factors in detritus-based ecosystems

To date, most researchers working in stoichiometry have overlooked the existence of other resources quality parameters that could explain the limitation of consumers and/or biological production in ecosystems. From the very beginning, some researchers have rejected the stoichiometric theory by opposing, for example, the role of polyunsaturated fatty acids (MüllerNavarra et al., 2000; Ravet et al., 2003) to those of resource elemental imbalances. The scarcity of exchange between these different research communities has certainly slowed down the development of joint and objective approaches to tackle this issue. It is only recently that some authors have brought elements allowing to reconcile, at least partly, the different approaches, suggesting that temperature could for example shift organisms from one type of limitation to another (Masclaux et al., 2009; Persson et al., 2011). An increasing number of studies currently suggest that particular compounds, such as polyunsaturated fatty acids, might, in some conditions, be important to consider as a complementary explanation of detritivores community structure, and, in turn, on ecosystem processes (Guo et al., 2016; Crenier et al., 2017). Unfortunately, these topics have not been fully addressed and data on the respective roles of stoichiometry and specific compounds limitations are still too scarce in the literature.

\section{ACKNOWLEDGEMENTS}

I greatly thank the Asociación Ibérica de Limnología and M.A.S. Graça in particular for inviting me as a keynote speaker for the AIL conference and welcoming me so warmly in Coimbra. I also thank I. Muñoz for her understanding and giving me more time for manuscript submission. Finally, this manuscript benefitted from the thoughts developed during the ANR StoichioMic program (ANR-18-CE32-0003-01) and the time for research offered by the Institut Universitaire de France.

\section{REFERENCES}

ALLEN, A. P. \& J. F. GILLOOLY. 2009. Towards an integration of ecological stoichiometry and the metabolic theory of ecology to better understand nutrient cycling. Ecology Letters, 12(5): 369-384. DOI: 10.1111/j.14610248.2009.01302.x

ANDERSON, T. R., D. O. HESSEN, J. J. ELSER \& J. URABE. 2004. Metabolic stoichiometry and the fate of excess carbon and nutrients in consumers. The American Naturalist, 165(1): 1-15. DOI: $10.1086 / 426598$

ARCE FUNCK J., C. CRENIER, M. DANGER, C. COSSU-LEGUILLE, F. GUÉROLD \& V. FELTEN. 2016. Stoichiometric constraints modulate the impact of contaminants: an experimental approach using the detritivore, Gammarus fossarum. Freshwater Biology, 61 
(12): 2075-2089. DOI: 10.1111/fwb.12785

ARRIGO, K. R. 2005. Marine microorganisms and global nutrient cycles. Nature, 437: 349-355. DOI: 10.1038/nature04159

BACK, J. A. \& R. S. KING. 2013. Sex and size matter: ontogenetic patterns of nutrient content of aquatic insects. Freshwater Science, 32(3): 837-848 DOI: $10.1899 / 12-181.1$

BEC, A., M. E. PERGA, A. KOUSSOROPLIS, G. BARDOUX, C. DESVILETTES, G. BOURDIER \& A. MARIOTTI. 2011. Assessing the reliability of fatty acid-specific stable isotope analysis for trophic studies. Methods in Ecology and Evolution, 2(6): 651-659. DOI: 10.1111/j.2041-210x.2011.00111.x

BENSTEAD, J. P., J. M. HOOD, N. V. WHELAN, M. R. KENDRICK, D. NELSON, A.F. HANNINEN \& L. M. DEMI. 2014. Coupling of dietary phosphorus and growth across diverse fish taxa: a meta-analysis of experimental aquaculture studies. Ecology, 95(10): 2768-2777. DOI: 10.1890/13-1859.1

BIASI, C., M. A. S. GRAÇA \& V. FERREIRA. 2017. Nutrient enrichment in water more than in leaves affects aquatic microbial litter processing. Oecologia, 184(2): 555-568. DOI: 10.1007/s00442-017-3869-5

BOERSMA, M. \& J. J. ELSER. 2006. Too much of a good thing: on stoichiometrically balanced diets and maximal growth. Ecology, 87(5): 1325-1330. DOI: $10.1890 / 0012-9658$ (2006)87[1325:tmoagt]2.0.co;2

CEBRIAN, J., J. B. SHURIN, E.T. BORER, B. J. CARDINALE, J. T. NGAI, M. D. SMITH \& W. F. FAGAN. 2009. Producer nutritional quality controls ecosystem trophic structure. PloS One, 4(3): e4929. DOI: 10.1371/journal. pone.0004929

CHAPIN III, F. S. 1980. The mineral nutrition of wild plants. Annual review of ecology and systematics, 11(1): 233-260. DOI: 10.1007/ 978-94-009-3581-5 2

CHEEVER, B. M., E. B. KRATZER \& J. R. WEBSTER. 2012. Immobilization and mineralization of $\mathrm{N}$ and $\mathrm{P}$ by heterotrophic microbes during leaf decomposition. Freshwater Science, 31: 133-147. DOI: 10.1899/ 11-060.1

CHERIF, M., C. FAITHFulL, J. GUO, C.L.
MEUNIER, J. SITTERS, W. USZKO \& F. RIVERA VASCONCELOS. 2017. An operational framework for the advancement of a molecule-to-biosphere stoichiometry theory. Frontiers in Marine Science, 4: 286. DOI: 10.3389/fmars.2017.00286

CHRZANOWSKI, T. H. \& M. KYLE. 1996. Ratios of carbon, nitrogen and phosphorus in Pseudomonas fluorescens as a model for bacterial element ratios and nutrient regeneration. Aquatic Microbial Ecology, 10: 115-122. DOI: $10.3354 / \mathrm{ame} 010115$

CRENIER C., J. ARCE-FUNCK, A. BEC, F. PERRIÈRE, J. LEFLAIVE, F. GUÉROLD, V. FELTEN \& M. DANGER. 2017. Minor food sources can be major drivers of secondary production in detritus-based ecosystems. Freshwater Biology, 62 (7): 1155-1167. DOI: 10.1111/fwb.12933

CROSS, W. F., J. B. WALLACE \& A. D. ROSEMOND. 2007. Nutrient enrichment reduces constraints on material flows in a detritus-based food web. Ecology, 88(10): 2563-2575. DOI: 10.1890/06-1348.1

CROSS, W. F., J. P. BENSTEAD, P. C. FROST \& S. A. THOMAS. 2005. Ecological stoichiometry in freshwater benthic systems: recent progress and perspectives. Freshwater Biology, 50: 1895-1912. DOI: 10.1111/j.1365-2427. 2005.01458.x

CROSS, W. F., J. B. WALLACE, A. D. ROSEMOND \& S. L. EGGERT. 2006. Whole-system nutrient enrichment increases secondary production in a detritus-based ecosystem. Ecology, 87(6): 1556-1565. DOI: 10.1890/0012-9658(2006)87[1556:wneisp]2 . $0 . \operatorname{co} ; 2$

CROSS, W. F., J. P. BENSTEAD, A. D. ROSEMOND \& J. B. WALLACE. 2003. Consumer-resource stoichiometry in detritus-based streams. Ecology Letters, 6(8): 721-732. DOI: 10.1046/j.1461-0248.2003. 00481.x

CYR, H. \& M. L. PACE. 1993. Magnitude and patterns of herbivory in aquatic and terrestrial ecosystems. Nature, 361: 148-150. DOI: 10.1038/361148a0

DANG, C. K., S. HARRISON, M.M. STURT, P. S. GILLER \& M. A. JANSEN. 2009. Is the 
elemental composition of stream invertebrates a determinant of tolerance to organic pollution? Journal of the North American Benthological Society, 28(4): 778-784. DOI: 10.1899/08-163.1

DANGER, M., \& E. CHAUVET. 2013. Elemental composition and degree of homeostasis of fungi: are aquatic hyphomycetes more like metazoans, bacteria, or plants? Fungal Ecology, 6: 453-457. DOI: 10.1016/j.funeco.2013. 05.007

DANGER, M., J. CORNUT, A. ELGER \& E. CHAUVET. 2012. Effects of burial on leaf litter quality, microbial conditioning and palatability to three shredder taxa. Freshwater Biology, 57 (5): 1017-1030. DOI: 10.1111/j. 365-2427.2012.02762.x

DANGER, M., T. DAUFRESNE, F. LUCAS, S. PISSART \& G. LACROIX. 2008. Does Liebig's law of the minimum scale up from species to communities? Oikos, 117: 1741-1751. DOI: 10.1111/j.0030-1299.2008.16793.x

DANGER, M., M. O. GESSNER \& F. BÄRLOCHER. 2016. Ecological stoichiometry of aquatic fungi: current knowledge and perspectives. Fungal Ecology, 19: 100-111. DOI: 10.1016/j.funeco.2015.09.004

DANGER, M., J. ARCE FUNCK, S. DEVIN, J. HEBERLÉ \& V. FELTEN. 2013b. Phosphorus content in detritus controls life history traits of a detritivore. Functional Ecology, 27: 807-815. DOI: 10.1111/1365-2435.12079

DANGER, M., J. CORNUT, E. CHAUVET, P. CHAVEZ, A. ELGER \& A. LECERF. 2013a. Benthic algae stimulate leaf litter decomposition in detritus-based headwater streams: a case of aquatic priming effect? Ecology, 94: 1604-1613. DOI: 10.1890/12-0606.1

DARCHAMBEAU, F., P. J. FAERØVIG \& D. O. HESSEN. 2003. How Daphnia copes with excess carbon in its food. Oecologia, 136(3): 336-346. DOI: 10.1007/s00442-003-1283-7

DEMI, L. M., J. P. BENSTEAD, A. D. ROSEMOND \& J. C. MAERZ. 2019. Experimental $\mathrm{N}$ and $\mathrm{P}$ additions alter stream macroinvertebrate community composition via taxon-level responses to shifts in detrital resource stoichiometry. Functional Ecology. 33: 855-867. DOI: 10.1111/1365-2435.13289
DEMI, L. M., J. P. BENSTEAD, A. D. ROSEMOND \& J. C. MAERZ. 2018. Litter P content drives consumer production in detritus-based streams spanning an experimental N: P gradient. Ecology, 99(2): 347-359. DOI: 10.1002/ecy. 2118

DEMOTT, W. R., R. D. GULATI \& K. SIEWERTSEN. 1998. Effects of phosphorus-deficient diets on the carbon and phosphorus balance of Daphnia magna. Limnology and Oceanography, 43(6): 1147-1161. DOI: 10.4319/10.1998.43.6.1147

ELSER, J. J. \& J. URABE. 1999. The stoichiometry of consumer-driven nutrient recycling: theory, observations, and consequences. Ecology, 80(3): 735-751. DOI: 10.2307/177013

ELSER, J. J., T. H. CHRZANOWSKI, R. W. STERNER \& K. H. MILLS. 1998. Stoichiometric constraints on food-web dynamics: A whole-lake experiment on the Canadian Shield. Ecosystems, 1: 120-136. DOI: 10.1007/ s100219900009

ELSER, J. J., D. DOBBERFUHL, N. A. MACKAY \& J. H. SCHAMPEL. 1996. Organism size, life history, and N:P stoichiometry: Towards a unified view of cellular and ecosystem processes. Bioscience, 46: 674-684. DOI: 10.2307/1312897

ELSER, J. J., K. HAYAKAWA \& J. URABE. 2001. Nutrient limitation reduces food quality for zooplankton: Daphnia response to seston phosphorus enrichment. Ecology, 82(3): 898-903. DOI: $10.2307 / 2680208$

EVANS-WHITE, M. A. \& H. M. HALVORSON. 2017. Comparing the ecological stoichiometry in green and brown food webs-a review and meta-analysis of freshwater food webs. Frontiers in microbiology, 8: 1184. DOI: $10.3389 /$ fmicb.2017.01184

EVANS-WHITE, M. A., W. K. DODDS, D. G. HUGGINS \& D. S. BAKER. 2009. Thresholds in macroinvertebrate biodiversity and stoichiometry across water-quality gradients in Central Plains (USA) streams. Journal of the North American Benthological Society, 28(4): 855-868. DOI: 10.1899/08-113.1

FANIN, N., N. FROMIN, B. BUATOIS \& S. HÄTTENSCHWILER. 2013. An experimental test of the hypothesis of non-homeostatic 
consumer stoichiometry in a plant litter-microbe system. Ecology letters, 16(6): 764-772. DOI: 10.1111/ele.12108

FARRELL, K. J., A. D. ROSEMOND, J. S. KOMINOSKI, S. M. BONJOUR, J. RÜEGG, L. E. KOENIG, C. L. BAKER, M. T., TRENTMAN, T. K. HRMS \& W. H. MCDOWELL. 2018. Variation in detrital resource stoichiometry signals differential carbon to nutrient limitation for stream consumers across biomes. Ecosystems, 21: 1676-1691. DOI: 10.1007/s10021-018-0247-z

FELTEN, V., G. TIXIER, F. GUÉROLD, A. DE CRESPIN \& O. DANGLES. 2008. Quantification of diet variability in a stream amphipod: Implications for ecosystem functioning. Fundamental and Applied Limnology/Archiv für Hydrobiologie, 170: 303-313. DOI: 10.1127/1863-9135/2008/0170-0303

FERREIRA, V., B. CASTAGNEYROL, J. KORICHEVA, V. GULIS, E. CHAUVET \& M. A. S. GRAÇA. 2014. A meta-analysis of the effects of nutrient enrichment on litter decomposition in streams. Biological Reviews, 90: 669-688. DOI: 10.1111/brv.12125

FERREIRA, V., A. L. GONCALVES, D. L. GODBOLD \& C. CANHOTO. 2010. Effect of increased atmospheric $\mathrm{CO} 2$ on the performance of an aquatic detritivore through changes in water temperature and litter quality. Global Change Biology, 16: 3284-3296. DOI: 10.1111/j.1365-2486.2009.02153.x

FISHER, S. G. \& G. E. LIKENS. 1973. Energy flow in Bear Brook, New Hampshire: An integrative approach to stream ecosystem metabolism. Ecological Monographs, 43: 421-439. DOI: 10.2307/1942301

FRIBERG, N., \& D. JACOBSEN. 1999. Variation in growth of the detritivore-shredder Sericostoma personatum (Trichoptera). Freshwater Biology, 42(4): 625-635. DOI: 10.1046/j.1365-2427.1999.00501.x

FROST P. C. \& J. J. ELSER. 2002. Growth responses of littoral mayflies to the phosphorus content of their food. Ecology Letters, 5: 232-240. DOI: 10.1046/j.1461-0248.2002. 00307.x

FROST, P. C., J. P. BENSTEAD, W. F. CROSS, H. HILLEBRAND, J. H. LARSON, M. A.
XENOPOULOS \& T. YOSHIDA. 2006. Threshold elemental ratios of carbon and phosphorus in aquatic consumers. Ecology Letters, 9(7): 774-779. DOI: 10.1111/j.14610248.2006.00919.x

FROST, P. C., J. J. ELSER \& M. A. TURNER. 2002. Effects of caddisfly grazers on the elemental composition of epilithon in a boreal lake. Journal of the North American Benthological Society, 21: 54-63. DOI: 10.2307/1468299

FROST, P. C. \& N. C. TUCHMAN. 2005. Nutrient release rates and ratios by two stream detritivores fed leaf litter grown under elevated atmospheric $\mathrm{CO}_{2}$. Archiv für Hydrobiologie, 163: 463-477. DOI: 10.1127/00039136/2005/0163-0463

FULLER, C. L., M. A. EVANS-WHITE \& S. A. ENTREKIN. 2015. Growth and stoichiometry of a common aquatic detritivore respond to changes in resource stoichiometry. Oecologia, 177: 837-848. DOI: 10.1007/s00442-0143154-9

GESSNER, M. O. \& E. CHAUVET. 1994. Importance of stream microfungi in controlling breakdown rates of leaf litter. Ecology, 75(6): 1807-1817. DOI: 10.2307/ 1939639

GESSNER, M. O., E. CHAUVET \& M. DOBSON. 1999. A perspective on leaf litter breakdown in streams. Oikos, 85: 377-384. DOI: $10.2307 / 3546505$

GODWIN, C. M. \& J. B. COTNER. 2014. Carbon: phosphorus homeostasis of aquatic bacterial assemblages is mediated by shifts in assemblage composition. Aquatic Microbial Ecology, 73(3): 245-258. DOI: 10.3354/ me01719

GONZALEZ, A. L., G. Q. ROMERO \& D. SRIVASTAVA. 2014. Detrital nutrient content determines growth rate and elemental composition on bromeliad-dwelling insects. Freshwater Biology, 59: 737-747. DOI: 10.1111/fwb. 12300

GRAÇA, M. A. S., F. BÄRLOCHER \& M. O. GESSNER (Eds.). 2005. Methods to study litter decomposition: a practical guide. Springer Science \& Business Media. Springer, Berlin. 
GRAÇA, M. A. S., \& J. M. POQUET. 2014. Do climate and soil influence phenotypic variability in leaf litter, microbial decomposition and shredder consumption?. Oecologia, 174(3): 1021-1032. DOI: 10.1007/s00442013-2825-2

GRIMMETT, I. J., K. A. SMITH, \& F. BÄRLOCHER. 2012. Tar-spot infection delays fungal colonization and decomposition of maple leaves. Freshwater Science, 31(4): 1088-1095. DOI: 10.1899/12-034.1

GULIS, V., K. A. KUEHN, L. N. SCHOETTLE, L. N. LEACH, J. P. BENSTEAD \& A. D. ROSEMOND. 2017. Changes in nutrient stoichiometry, elemental homeostasis and growth rate of aquatic litter-associated fungi in response to inorganic nutrient supply. The ISME journal, 11(12): 2729. DOI: 10.1038/ ismej.2017.123

GUO, F., M. KAINZ, F. SHELDON \& S. E. BUNN. 2016. The importance of high-quality algal food sources in stream food webs-current status and future perspectives. Freshwater Biology, 61(6): 815-831. DOI: 10.1111/fwb. 12755

HAIRSTON, N. G. JR \& N. G. Sr HAIRSTON. 1993. Cause-effect relationships in energy flow, trophic structure, and interspecific interactions. The American Naturalist, 142: 379-411. DOI: $10.1086 / 285546$

HALVORSON, H. M., \& G. E. SMALL. 2016. Observational field studies are not appropriate tests of consumer stoichiometric homeostasis. Freshwater Science, 35(4): 1103-1116. DOI: 10.1086/689212

HALVORSON, H. M., J. T. SCOTT, A. J. SANDERS \& M. A. EVANS-WHITE. 2015. A stream insect detritivore violates common assumptions of threshold elemental ratio bioenergetics models. Freshwater Science, 34(2): 508-518. DOI: 10.1086/680724

HENDRIXSON, H. A., R.W. STERNER \& A. D. KAY. 2007. Elemental stoichiometry of freshwater fishes in relation to phylogeny, allometry and ecology. Journal of Fish Biology, 70(1): 121-140. DOI: 10.1111/j.10958649.2006.01280.x

HLADYZ, S., M. O. GESSNER, P. S. GILLER, J. POZO \& G. WOODWARD. 2009.
Resource quality and stoichiometric constraints on stream ecosystem functioning. Freshwater Biology, 54(5): 957-970. DOI: 10.1111/j.1365-2427.2008.02138.x

KENDRICK, M. R. \& J. P. BENSTEAD. 2013. Temperature and nutrient availability interact to mediate growth and body stoichiometry in a detritivorous stream insect. Freshwater Biology, 58(9): 1820-1830. DOI: 10.1111/fwb.12170

KHATTAK, H. K., C. PRATER, N. D. WAGNER \& P. C. FROST. 2018. The threshold elemental ratio of carbon and phosphorus of Daphnia magna and its connection to animal growth. Scientific reports, 8(1): 9673. DOI: $10.1038 / \mathrm{s} 41598-018-27758-7$

KILLINGBECK, K. T. 1996. Nutrients in senesced leaves: keys to the search for potential resorption and resorption proficiency. Ecology, 77(6): 1716-1727. DOI: 10.2307/2265777

KOOIJMAN, S. A. L. M. 2000. Dynamic energy and mass budgets in biological systems. Cambridge University Press, Cambridge, UK

LAURIDSEN, R. B., F. K. EDWARDS, W. F. CROSS, G. WOODWARD, A. G. HILDREW \& J. I. JONES. 2014. Consequences of inferring diet from feeding guilds when estimating and interpreting consumer resource stoichiometry. Freshwater Biology, 59: 1497-1508. DOI: $10.1111 /$ fwb. 12361

LECERF, A. \& E. CHAUVET. 2008. Intraspecific variability in leaf traits strongly affects alder leaf decomposition in a stream. Basic and Applied Ecology, 9: 598-605. DOI: 10.1016/j.baae.2007.11.003

LINDEMAN, R. L. 1942. The trophic-dynamic aspect of ecology. Ecology, 23: 399-418. DOI: $10.2307 / 1930126$

LITCHMAN, E., \& C. A. KLAUSMEIER. 2008. Trait-based community ecology of phytoplankton. Annual Review of Ecology, Evolution and Systematics, 39: 615-639. DOI: 10.1146/annurev.ecolsys.39.110707.173549

LITCHMAN, E., M. D. OHMAN \& T. KIØRBOE. 2013. Trait-based approaches to zooplankton communities. Journal of Plankton Research, 35: 473-484. DOI: 10.1093/plankt/ fbt019

LOTKA, A.J. 1925. Elements of Physical Biology. Williams and Wilkins, Baltimore. 
MACARTHUR, R. H. 1972. Geographical ecology: patterns in the distribution of species. Princeton University Press, Princeton, NJ.

MANNING, D. W., A. D. ROSEMOND, J. S. KOMINOSKI, V. GULIS, J. P. BENSTEAD \& J. C. MAERZ. 2015. Detrital stoichiometry as a critical nexus for the effects of streamwater nutrients on leaf litter breakdown rates. Ecology, 96(8): 2214-2224. DOI: 10.1890/14-1582.1

MARTINSON, H. M., K. SCHNEIDER, J. GILBERT, J., J. E. HINES, P. A. HAMBACK \& W. F. FAGAN. 2008. Detritivory: stoichiometry of a neglected trophic level. Ecological Research, 23: 487-491. DOI: 10.1007/ s11284-008-0471-7

MASCLAUX, H., A. BEC, M. KAINZ, C. DESVILETTES, L. JOUVE \& G. BOURDIER. 2009. Combined effects of food quality and temperature on somatic growth and reproduction of two freshwater cladocerans. Limnology and Oceanography, 54(4): 1323-1332. DOI: 10.4319/1o.2009.54.4.1323

MAS-MARTI, E., A. M. ROMANI \& I. MUNOZ. 2015. Consequences of warming and resource quality on the stoichiometry and nutrient cycling of a stream shredder. PLOS One, 10 (3), 0118520. DOI: 10.1371/journal. one. 0118520

MEUNIER, C. L., M. BOERSMA, R. EL-SABAAWI, H. M. HALVORSON, E. M. HERSTOFF, D. VAN DE WAAL \& E. LITCHMAN. 2017. From elements to function: Toward unifying ecological stoichiometry and trait-based ecology. Frontiers in Environmental Science, 5: 18. DOI: 10.3389/fenvs. 2017.00018

MEUNIER, C. L., A. M. MALZAHN \& M. BOERSMA. 2014. A new approach to homeostatic regulation: towards a unified view of physiological and ecological concepts. PLoS One, 9: e107737. DOI: 10.1371/journal.pone. 0107737

MOE, S. J., R. S. STELZER, M. R. FORMAN, W. S. HARPOLE, T. DAUFRESNE \& T. YOSHIDA. 2005. Recent advances in ecological stoichiometry: insights for population and community ecology. Oikos, 109: 29-39. DOI: 10.1111/j.0030-1299.2005.14056.x
MOORE, J. C., E. L. BERLOW, D. C. COLEMAN, P. C. DE RUITER, Q. DONG, A. HASTINGS, N. C. JOHNSON, K. S. MCCANN, K. MELVILLE, P. J. MORIN, K. NADELHOFFER, A. D. ROSEMOND, D. M. POST, J. L. SABO, K. M. SCOW, M. J. VANNI \& D. H.WALL. 2004. Detritus, trophic dynamics and biodiversity. Ecology Letters, 7: 584-600. DOI: 10.1111/j.14610248.2004.00606.x

MÜLLER-NAVARRA, D. C., M. T. BRETT, A. M. LISTON \& C. R. GOLDMAN. 2000. A highly unsaturated fatty acid predicts carbon transfer between primary producers and consumers. Nature, 403(6765): 74-77. DOI: 10.1038/47469

NOODÉN, L. D., J. J. GUIAMÉT \& I. JOHN. 1997. Senescence mechanisms. Physiologia plantarum, 101(4): 746-753. DOI: 10.1034/j. 1399-3054.1997.1010410.x

ODUM, E. P. 1969. The strategy of ecosystem development. Science, 164: 262-279. DOI: 10.1126/science.164.3877.262

OSTROFSKY, L. 1997. Relationship between chemical characteristics of autumn-shed leaves and aquatic processing rates. Journal of the North American Benthological Society, 16: 750-759. DOI: $10.2307 / 1468168$

PERSSON, J., P. FINK, A. GOTO, J. M. HOOD, J. JONAS \& S. KATO. 2010. To be or not to be what you eat: regulation of stoichiometric homeostasis among autotrophs and heterotrophs. Oikos, 119(5): 741-751. DOI: 10.1111/ j.1600-0706.2010.18545.x

PERSSON, J., M. W. WOJEWODZIC, D. O. HESSEN \& T. ANDERSEN. 2011. Increased risk of phosphorus limitation at higher temperatures for Daphnia magna. Oecologia, 165(1): 123-129. DOI: 10.1007/s00442-0101756-4

POLIS, G. A. \& D. R. STRONG. 1996. Food web complexity and community dynamics. The American Naturalist, 147: 813-846. DOI: $10.1086 / 285880$

QUÉVREUX, P., S. BAROT \& É. THÉBAULT. 2018. Impact of nutrient cycling on food web stability. bioRxiv, 276592. DOI: 10.1101/ 276592

RAVET, J. L., M. T. BRETT \& D. C. 
MÜLLER-NAVARRA. 2003. A test of the role of polyunsaturated fatty acids in phytoplankton food quality for Daphnia using liposome supplementation. Limnology and Oceanography, 48(5): 1938-1947. DOI: 10.1086/ 284467

REINERS, W. A. 1986. Complementary models for ecosystems. The American Naturalist, 127: 59-73.

RIBBLETT, S. G., M. A. PALMER \& D. WAYNE COATS. 2005. The importance of bacterivorous protists in the decomposition of stream leaf litter. Freshwater Biology, 50(3): 516-526. DOI: 10.1111/j.1365-2427.2005. 01338.x

ROLLIN, M., R. COULAUD, M. DANGER, B. SOHM, J. FLAYAC, A. CHAUMOT, O. GEFFARD \& V. FELTEN. 2018. Additive effect of calcium depletion and low resource quality on Gammarus fossarum (Crustacea, Amphipoda) life history traits. Environmental Science and Pollution Research, 25 (12): 11264-11280. DOI: $10.1007 / \mathrm{s} 11356-017-$ 9390-х

RUIZ, T., A. BEC, M. DANGER, A. M. KOUSSOROPLIS, J. P. AGUER, J. P. MOREL \& N. MOREL-DESROSIERS. 2018. A microcalorimetric approach for investigating stoichiometric constraints on the standard metabolic rate of a small invertebrate. Ecology Letters, 21 (11): 1714-1722. DOI: 10.1111/ ele. 13137

RUIZ, T., A. M. KOUSSOROPLIS, M. DANGER, J. P. AGUER, N. MOREL-DESROSIERS \& A. BEC. 2019. The Threshold Elemental Ratio of an ectotherm decreases then increases with rising temperature. bioRxiv, 681239. DOI: $10.1101 / 681239$

SCHATZ, G. S. \& E. MCCAULEY. 2007. Foraging behavior by Daphnia in stoichiometric gradients of food quality. Oecologia, 153: 1021-1030. DOI: 10.1007/s00442-007-0793-0

SMALL, G. E. \& C. M. PRINGLE. 2010. Deviation from strict homeostasis across multiple trophic levels in an invertebrate consumer assemblage exposed to high chronic phosphorus enrichment in a Neotropical stream. Oecologia, 162(3): 581-590. DOI: 10.1007/s00442009-1489-4
STELZER, R. S. \& G. A. LAMBERTI. 2002. Ecological stoichiometry in running waters: Periphyton chemical composition and snail growth. Ecology, 83: 1039-1051. DOI: 10.1890/0012-9658(2002)083[1039:esirwp] 2.0.co;2

STERNER, R. W. \& J. J. ELSER. 2002. Ecological stoichiometry: the biology of elements from molecules to the biosphere. Princeton University Press, Princeton, USA.Sterner \& Hessen 1994

SUBERKROPP, K., G. L. GODSHALK \& M. J. KLUG. 1976. Changes in the chemical composition of leaves during processing in a woodland stream. Ecology, 57(4): 720-727. DOI: $10.2307 / 1936185$

SWIFT, M.J., O. W. HEAL \& J. M. ANDERSON. 1979. Decomposition in Terrestrial Ecosystems. University of California Press, Berkeley, CA, USA.

TILMAN, D. 1980. Resources: a graphical-mechanistic approach to competition and predation. The American Naturalist, 116(3): 362-393. DOI: $10.1086 / 283633$

TILMAN, D. 1982. Resource competition and community structure. Princeton University Press, Princeton, 360pp

URABE, J., Y. SHIMIZU \& T. YAMAGUCHI. 2018. Understanding the stoichiometric limitation of herbivore growth: the importance of feeding and assimilation flexibilities. Ecology letters, 21(2): 197-206. DOI: 10.1111/ ele. 12882

VANNI, M. J., \& P. B. MCINTYRE. 2016. Predicting nutrient excretion of aquatic animals with metabolic ecology and ecological stoichiometry: a global synthesis. Ecology, 97(12): 3460-3471. DOI: 10.1002/ecy.1582

WALLACE, J. B., S. L. EGGERT, J. L. MEYER \& J. R. WEBSTER. 1999. Effects of resource limitation on a detrital-based ecosystem. Ecological Monographs, 69(4): 409-442.

WOODS, H. A., W. F. FAGAN, J. J. ELSER \& J. F. HARRISON. 2004. Allometric and phylogenetic variation in insect phosphorus content. Functional Ecology, 18(1): 103-109. DOI: $10.1111 / \mathrm{j} .1365-2435.2004 .00823 . \mathrm{x}$

YAMAMICHI, M., C. L. MEUNIER, A. PEACE, C. PRATER \& M. A. RUA. 2015. Rapid evolu- 
tion of a consumer stoichiometric trait destabilizes consumer-producer dynamics. Oikos, 124(7): 960-969. DOI: 10.1111/oik.02388

ZOU, K., E. THEBAULT, G. LACROIX \& S.
BAROT. 2016. Interactions between the green and brown food web determine ecosystem functioning. Functional Ecology, 30(8): 1454-1465. DOI: 10.1111/1365-2435.12626

Con el patrocinio de:

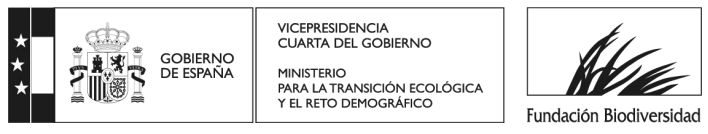

